\title{
CORRIGENDUM
}

\section{Girdin maintains the stemness of glioblastoma stem cells}

A Natsume, T Kato, S Kinjo, A Enomoto, H Toda, S Shimato, F Ohka, K Motomura, Y Kondo, T Miyata, M Takahashi and T Wakabayashi

Oncogene (2017) 36, 3796; doi:10.1038/onc.2017.17; published online 20 February 2017

Correction to: Oncogene (2012) 31, 2715-2724; doi:10.1038/ onc.2011.466; published online 24 October 2011

Since the publication of the above article, it has been noted that the gel images of 0323-BTSCs in Figure $2 \mathrm{~b}$ should be replaced because the LaminA/C bands used as internal controls were mistakenly cropped.

The corrected figure is below.

The authors would like to apologise for this error.

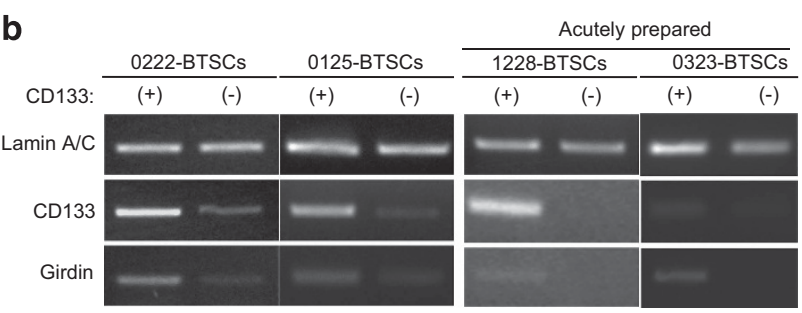

Figure 2. 